\title{
ANALISIS WACANA IKLAN PERAWATAN KULIT WAJAH PADA MAJALAH FEMME ACTUELLE (Pendekatan Mikrostruktural dan Makrostruktural)
}

\author{
Siti Perdi Rahayu \\ Fakultas Bahasa dan Seni Universitas Negeri Yogyakarta \\ e-mail :perdi_rahayu@yahoo.fr
}

\begin{abstract}
ABSTRAK
Penelitian ini bertujuan untuk mendeskripsikan aspek-aspek kohesi dan koherensi yang terdapat dalam iklan perawatan kulit wajah Crème Bienfaisante, NIVEA Q10, Idéalia Life Serum, dan IXXI Pearlixime pada majalah Femme Actuelle. Metode Pengumpulan data yang digunakan adalah metode simak dengan teknik dasar teknik sadap dan teknik lanjutan SBLC (Simak Bebas Libat Cakap), serta teknik catat dan diakhiri dengan klasifikasi. Untuk menganalisis data digunakan metode agih dan metode padan. Hasil penelitian menunujukan bahwa Penggunaan aspek kohesi dalam wacana iklan Perawatan Kulit Wajah (Crème Bienfaisante, NIVEA Q10, Idéalia Life Serum, dan IXXI Pearlixime) adalah sebagai berikut: elipsis sebanyak 36 (35,65\%), konjungsi/perangkai 32 (31,69\%), repetisi $12(11,89)$, referensi $6(5,94 \%)$, kolokasi $7(6,93 \%)$, substitusi $4(3,96 \%)$, sinonim dan hiponimi masing-masing 2 (1,98\%). Jenis kohesi elipsis adalah yang paling banyak digunakan. Elipsis ini berfungsi menimbulkan rasa penasaran atau ingin tahu dari pembaca terhadap hal-hal yang tidak diungkapkan dalam teks. Aspek koherensi meliputi hubungan makna: penambahan $9(30 \%)$, kewaktuan $7(23,34 \%)$, penjelas $5(16,67 \%)$, tempat $3(10 \%)$, kepemilikan dan persyaratan masing-masing $2(6,67 \%)$, tujuan dan perbandingan masingmasing $1(3,34 \%)$. Semua wacana iklan perawatan kulit wajah memberikan informasi yang khusus dan terperinci tentang produk, menampilkan foto produk dan model, disertai dengan ilustrasi yang jelas tentang pesan produk. Pada umumnya, perawatan kulit wajah bertujuan untuk membuat kulit wajah wanita tidak kelihatan tua, mencegah timbulnya atau menghilangkan keriput. Di samping itu, kulit wajah wanita diharapkan harus selalu kelihatan segar, ceria, tidak kusam, dan tidak kelihatan capai. Perawatan kulit wajah ini juga harus dilakukan setiap hari, dengan krim pagi dan krim malam. serta serum yang bisa digunakan setiap saat
\end{abstract}

Kata kunci: Wacana, Iklan, Kohesi, Referen, Substitusi, Elipsis, Konjungsi, Kolokasi, Koherensi

\section{A DISCOURSE ANALYSIS OF FACIAL SKIN CARE ADVERTISEMENTS IN FEMME ACTUELLE MAGAZINE (Microstructural and Macrostructural Approaches)}

\begin{abstract}
This research aims to describe 1) cohesion and coherence aspects in the facial skin care advertisements of Crème Bienfaisante, NIVEA Q10, Idéalia Life Serum, and IXXI Pearlixime published in Femme Actuelle Magazine No. 1523, 2-8 December 2013, 2 ) the meanings of the aspects related to the situational and cultural contexts. To collect the data, the observation method was applied with tapping technique, uninvolved conversation observation technique, writing technique, and classification technique. In analyzing the data, distributional and identity methods were applied to know the forms of cohesion and coherence, and the overall meaning of the advertisements related to the situational and cultural contexts. The result shows that the cohesion aspect in the discourse of facial skin care advertisements of Crème Bienfaisante, NIVEA Q10, Idéalia Life Serum, and IXXI Pearliximeis used as follows: ellipsis 36 (35,65\%), conjuction $32(31,69 \%)$, repetition 12 $(11,89)$, reference $6(5,94 \%)$, collocation $7(6,93 \%)$, substitution $4(3,96 \%)$, synonymand
\end{abstract}


hyponym 2 for each (1,98\%). Ellipsis is the most frequently used. Ellipsis functions to create readers' curiosity of matters not revealed in the texts. Coherence aspect covers the relation of meaning: addition $9(30 \%)$, time $7(23,34 \%)$, explanation $5(16,67 \%)$, place $3(10 \%)$, possession and requirement 2 for each $(6,67 \%)$, purpose and comparison 1 for each $(3,34 \%)$. All discourses of facial skin care advertisements give specific and detailed information of the products, present the pictures of the products and models, and are accompanied with clear illustration of the product messages. In general facial skin care aims to prevent women's facial skin from looking old, and to avoid or remove wrinkles. Besides, it is expected that women's facial skin looks fresh, clean, and is prevented from dullness or weariness. The facial skin treatment has to be done daily with day cream and night cream, and serum that can be used at anytime.

Keywords: discourse, advertisement, cohesion, reference, substitution, ellipsis, conjunction, collocation, coherence.

\section{PENDAHULUAN}

Dalam kehidupan sehari-hari, manusia tidak dapat lepas dari manusia lain, dia akan hidup dan berkembang serta bekerja sama dengan manusia lain, sehingga mereka harus saling berinteraksi. Hal ini menunjukkan bahwa manusia adalah makhluk sosial, makhluk yang tidak dapat hidup sendiri. Salah satu yang dilakukan untuk dapat berkembang dan bekerja sama adalah dengan cara berkomunikasi. Komunikasi dalam kehidupan manusia saat ini dapat dilakukan dengan berbagai cara dan berbagai media. Komunikasi dapat terjadi secara langsung maupun tidak langsung. Komunikasi merupakan proses penyampaian pesan dari komunikator kepada komunikan melalui saluran tertentu, pesan bisa berupa lambang, suara, gambar, dan lain-lain (Suprapto, MS Tommy, 2009: 3). Salah satu bentuk komunikasi yang sangat sering kita jumpai dalam kehidupan sehari-hari adalah iklan.

Iklan merupakan media komunikasi yang selalu kita temui dalam kehidupan manusia sehari-hari, di televisi, koran, majalah, internet, spanduk, billboard di jalan-jalan. Iklan merupakan media untuk menyampaikan pesan secara kreatif dan persuasif Iklan dapat kita temui pada media cetak dan elektronik. Iklan pada media cetak hanya bisa menggunakan tulisan dan gambar, sedangkan iklan pada media elektronik bisa menggunakan tulisan, suara dan gambar bergerak. Oleh karena itu, untuk lebih menarik konsumen atau khalayak sasaran iklan di media cetak dibuat sekreatif dan semenarik mungkin.
Begitu banyaknya iklan dalam berbagai bahasa yang kita temui dalam kehidupan seharihari, maka iklan menjadi sangat layak untuk selalu menjadi objek penelitian. Dalam penelitian ini akan dibahas beberapa iklan berbahasa Prancis, untuk menemukan pesan-pesan yang akan disampaikan kepada khalayak sasarannya. Dari segi bahasanya, iklan tertentu hanya membutuhkan sedikit bahasa verbal, dan unsur non verbal lebih dominan. Dalam penelitian ini, iklan yang akan dianalisis memiliki bahasa verbal dan non verbal secara seimbang. Peneliti akan lebih menekankan analisisnya pada bahasa verbal, yang tentu saja tidak akan meninggalkan bahasa non verbal begitu saja.

Iklan yang diteliti adalah iklan Perawatan Kulit Wajah yang terdapat pada majalah Femme Actuelle no 1523 du 2 au 8 décembre 2013, yaitu iklan Crème Bienfaisante, NIVEA Q10, dan Idéalia Life Serum. Alasan yang mendasari dipilihnya iklan ini sebagai subjek dan objek penelitian, karena produk yang ditawarkan dalam iklan-iklan tersebut sangat potensial menarik para wanita untuk mencoba, membeli dan menggunakannya, serta ingin membuktikan kehebatan dari produk tersebut. Hal ini bisa dilihat pada testimoni dari para konsumennya.

Iklan merupakan salah satu bentuk wacana. Wacana adalah satuan lingual bahasa terlengkap, dalam hierarki gramatikal wacana merupakan satuan gramatikal tertinggi atau terbesar. Wacana itu direalisasikan dalam bentuk karangan yang utuh (novel, buku, seri ensiklopedia, dsb), paragraf, kalimat atau kata yang membawa amanat yang lengkap (Kridalakana, 
2008:259). Sedangkan Sumarlam dkk (2003: 15) meringkas dari berbagai batasan tentang wacana. Menurutnya wacana adalah satuan bahasa terlengkap yang dinyatakan secara lisan, seperti pidato, ceramah, khotbah, dan dialog, atau secara tertulis seperti cerpen, novel, buku, surat, dan dokumen tertulis, yang dilihat dari struktur lahirnya (dari segi bentuk) bersifat kohesif, saling terkait, dan dari struktur batinnya (dari segi makna) bersifat koheren, terpadu.

Berdasarkan bentuknya wacana dapat diklasifikasikan menjadi 3 (tiga) bentuk (Sumarlam dkk, 2003: 17), yaitu wacana prosa, wacana puisi, dan wacana drama. Wacana prosa adalah wacana yang disampaikan dalam bentuk prosa, yang dapat berupa wacana tulis (misalnya: cerpen, cerbung, novel, artikel, undang-undang, dsb) dan wacana lisan (pidato, khotbah, kuliah, dsb). Sedangkan wacana puisi adalah wacana yang disampaikan dalam bentuk puisi, dapat berbentuk tulis (puisi, syair) maupun lisan (puitisasi atau puisi yang dideklamasikan, lagulagu). Adapun wacana drama adalah wacana yang disampaikan dalam bentuk drama, dialog, baik berbentuk tulis (seperti naskah drama, sandiwara) maupun berbentuk lisan (seperti pemakaian bahasa pada pementasan drama atau percakapan antar pelaku.

Brown (1983: 1) menganalisis wacana berarti menganalisis penggunaan bahasa sesuai fungsinya. Dalam menganalisis wacana, deskripsi lingual sebuah bahasa tidak dapat dipisahkan dengan tujuan dan fungsi bentuk lingual tersebut yang memang dirancang sedemikian rupa untuk dipergunakan oleh manusia dalam berkomunikasi

Analisis wacana iklan dalam tulisan ini akan menggunakan pendekatan mikrostruktural. Yang dimaksud dengan pendekatan mikrostruktutural dalam analisis wacana iklan ini adalah analisis wacana yang memfokuskan pada aspek gramatikal yang menyangkut bentuk atau kohesi gramatikal, dan aspek leksikal yang menyangkut makna atau kohesi leksikal. Secara rinci aspek gramatikal wacana meliputi 4 hal (Sumarlam, 2003: 23-34), yaitu pengacuan (reference), penyulihan (substitusion), pelesapan (ellipsis), dan perangkaian (conjunction).

Adapun aspek leksikal (kohesi leksikal), yang bersama-sama dengan aspek gramatikal (kohesi gramatikal) mendukung kepaduan se-buah wacana, adalah hubungan antarunsur dalam wacana secara semantis. Kohesi leksikal ini dapat diklasifikasikan menjadi 6 (enam) macam (Sumarlam, 2003: 35-46), yaitu: 1) repetisi (pengulangan), 2) sinonimi (padan kata), 3) kolokasi (sanding kata), 4) hiponimi (hubungan atas bawah), 5) antonimi (lawan kata), dan 6) ekuivalensi (kesepadanan).

Koherensi adalah keterkaitan antara bagian yang satu dengan bagian yang lainnya, sehingga kalimat memiliki kesatuan makna yang utuh (Brown dan Yule dalam Mulyana, 2005: 30). Koherensi merupakan kontinuitas makna dalam teks. Bagian awal teks merupakan lingkungan bagi bagian selanjutnya, yang membentuk prakiraan internal. Prakiraan itu harus sejalan dengan prakiraan-prakiraan sebelumnya, yang telah dimiliki pendengar atau pembaca dari sumber-sumber luar, yaitu konteks situasi atau pun konteks budaya (Zaimmar, 2009: 85). Penanda koherensi yang digunakan dalam wacana bahasa Prancis dapat direalisasikan dengan nomina, pronomina, infinitif, gerondif, adverbia, dan klausa. Penanda-penanda tersebut dapat menyatakan adanya hubungan makna kewaktuan, hubungan makna cara, hubungan makna tempat, hubungan makna sebab, hubungan makna perbandingan, hubungan makna tujuan, hubungan makna akibat, hubungan makna penambahan, hubungan makna pejelasan, hubungan makna pertentangan, hubungan makna persyaratan, hubungan makna material, hubungan makna jumlah (harga, beban, jarak, dan lain-lain)

Analisis makrostruktural mengandung arti bahwa sebuah wacana dapat dianalisis dengan menggunakan pendekatan makrostruktural, yaitu pendekatan yang menitikberatkan pada susunan wacana secara global untuk memahami secara keseluruhan. Pendekatan makrostruktural mencakup konteks situasi dan konteks sosial budaya. Konteks situasi dan konteks budaya dapat dianalisis dengan berbagai prinsip penafsiran, yaitu: prinsip penafsiran personal, prinsip penafsiran lokal, prinsip penafsiran temporal, prinsip analogi (Sumarlam, 2003: 47). Ada hal-hal penting yang tak dapat ditinggalkan dalam memahami wacana dengan prinsip-prinsip penafsiran tersebut, yaitu: faktor sosial, faktor situasional, faktor kultural, dan 
faktor pengetahuan dunia (Halliday, 1985: 505).

Dalam analisis wacana konteks memiliki peran yang sangat penting, karena pada dasarnya, analisis wacana sama dengan menganalisis kata-kata dalam konteks. Mey (1994: 37) menjelaskan bahwa konteks adalah the surroundings...that enable the participants in the communication process to interact, and that make the linguistic expressions of their interaction intelligible "Konteks adalah lingkungan disekitar tuturan yang memungkinkan para peserta tutur dalam peristiwa komunikasi untuk berinteraksi dan membuat bentuk-bentuk lingual dalam interaksi mereka yang dapat dimengerti". Halliday dan Hasan (1994: 6) juga menguraikan bahwa konteks wacana adalah teks yang menyertai teks lain. Pengertian hal yang menyertai teks itu meliputi tidak hanya yang dilisankan dan tuliskan, tetapi termasuk pula kejadian-kejadian nonverbal lainnya-keseluruhan lingkungan teks itu. Dalam bidang etnografi komunikasi, Hymes (1972: 59) menawarkan seperangkat konsep tentang konteks dalam sebuah akronim SPEAKING, yaitu: $S=$ Setting atau Scene. $P=$ Participants. $E=$ Ends. $A=$ Act of Sequence. $K=$ Key. $I=$ Instrumentalities. $N=$ Norms of Interaction (norma interaksi). $G=$ Genre.

Berdasarkan uraian di atas, penelitian ini bertujuan untuk mendiskripsikan : 1) aspekaspek gramatikal dan aspek-aspek leksikal dalam iklan Perawatan Kulit Wajah pada majalah Femme Actuelle no 1523 du 2 au 8 décembre 2013, dan 2) makna aspek-aspek yang ditemukan tersebut sesuai dengan konteks komunikasi dalam iklan Perawatan Kulit Wajah pada majalah Femme Actuelle no 1523 du 2 au 8 décembre 2013 tersebut?

\section{METODE PENELITIAN}

Subjek Penelitian ini berupa iklan Perawatan kulit wajah, yang terdapat dalam majalah berbahasa Prancis Femme Actuelle no. 1523 du 2 au 8 décembre 2013, yaitu berupa iklan produk Crème Bienfaisante, NIVEA Q10, Idéalia Life Serum, dan Pearlixime IXXI, sedangkan objek Penelitiannya adalah lambang-lambang verbal dalam iklan tersebut, lambang non verbal akan menjadi konteks dalam memahami makna. Pengumpulan data menggunakan metode simak dengan teknik dasar teknik sadap dan teknik lanjutan SBLC (Simak Bebas Libat Cakap), serta teknik catat dan diakhiri dengan klasifikasi. Analisis data dalam penelitian ini menggunakan metode agih dan metode padan. Metode agih digunakan untuk mengetahui bentuk kohesi dan koherensi, sedangkan metode padan referensial digunakan untuk mengetahui makna iklan secara keseluruhan yang mempertimbangkan kontekssituasi dan budaya.

Uji validitas data yang digunakan adalah validitas semantis, yaitu mengukur tingkat kesensitifan suatu teknik terhadap makna-makna simbolik yang relevan dengan konteks tertentu. Makna semantis dapat dicapai apabila maknamakna tersebut berhubungan dengan penerima pesan, sumber pesan, isi pesan, dan konteks lainnya dari data-data yang dianalisis (Darmiyati, 1993: 75). Sedangkan uji reliabilitas adalah stabilitas yang didukung expert judgement, yaitu peneliti melakukan pembacaan berulang-ulang lambang-lambang yang ada dalam sumber data, yaitu iklan, dan apabila terdapat keraguan, peneliti berdiskusi dengan sesama dosen yang serumpun bidang ilmu atau dengan dosen senior atau ahli yang lebih menguasai bidang tersebut ((Darmiyati, 1993: 79)

\section{HASIL DAN PEMBAHASAN Hasil Penelitian}

Dari analisis data secara mikrostruktural ditemukan adanya penggunaan aspekaspek kohesi, baik kohesi gramatikal maupun kohesi leksikal (dapat dilihat pada Tabel 1), dan aspek koherensi (dapat dilihat pada Tabel 2). Sementara itu analisis secara makrostruktural akan disajikan dalah pembahasa,

Dari Tabel 1 diketahui bahwa untuk menunjang kepaduan wacana, Iklan Perawatan Kulit Wajah yang terdiri atas Crème Bienfaisante, NIVEA Q10, Idéalia Life Serum, dan ixxi pearlixime, menggunakan piranti kohesi gramatikal maupun leksikal, serta memiliki frekuensi. Hal ini menunjukkan bahwa wacana iklan Crème Bienfaisante, NIVEA Q10, Idéalia Life Serum, dan ixxi pearlixime dapat memanfaatkan piranti kohesi dengan baik, sehingga wacana pada iklan-iklan tersebut dapat dikatakan baik.

Dari tabel diatas dapat diketahui pulabahwa jenis kohesi yang paling banyak ditemui adalah kohesi gramatikal elipsis, yaitu sebanyak 
Tabel 1. Piranti Kohesi dalam Wacana Iklan Perawatan Kulit Wajah (Crème Bienfaisante, NIVEA Q10, Idéalia Life Serum, dan ixxi pearlixime)

\begin{tabular}{|c|c|c|c|c|c|c|c|}
\hline \multirow[b]{2}{*}{ No } & \multirow[b]{2}{*}{$\begin{array}{l}\text { Piranti } \\
\text { Kohesi }\end{array}$} & \multicolumn{4}{|c|}{ Jumlah data yang ditemukan } & \multirow[b]{2}{*}{ Jumlah } & \multirow[b]{2}{*}{$\%$} \\
\hline & & $\begin{array}{c}\text { Crème } \\
\text { Bienfaisante }\end{array}$ & NIVEA QI & $\begin{array}{l}\text { Idéalia Life } \\
\text { Serum }\end{array}$ & $\begin{array}{c}\text { ixxi } \\
\text { pearlixime }\end{array}$ & & \\
\hline 1 & Referensi & 2 & 2 & 2 & 0 & 6 & 5,94 \\
\hline 2 & Substitusi & 1 & 1 & 0 & 2 & 4 & 3,96 \\
\hline 3 & Elipsis & 21 & 6 & 4 & 5 & 36 & 35,65 \\
\hline 4 & $\begin{array}{l}\text { Konjungsi/ } \\
\text { perangkai }\end{array}$ & 14 & 9 & 5 & 4 & 32 & 31,69 \\
\hline 5 & Repetisi & 2 & 6 & 3 & 1 & 12 & 11,89 \\
\hline 6 & Sinonim & 1 & 1 & 0 & 0 & 2 & 1,98 \\
\hline 7 & Hiponimi & 1 & 1 & 0 & 0 & 2 & 1,98 \\
\hline 8 & Kolokasi & 4 & 127 & 1 & 1 & 7 & 6,93 \\
\hline & Jumlah & 46 & 27 & 15 & 13 & 101 & 100 \\
\hline
\end{tabular}

Tabel 2. Piranti Koherensi dalam Wacana Iklan Perawatan Kulit Wajah (Crème Bienfaisante, NIVEA Q10, Idéalia Life Serum, dan ixxi pearlixime))

\begin{tabular}{|c|c|c|c|c|c|c|c|}
\hline \multirow[b]{2}{*}{ No } & \multirow[b]{2}{*}{ Piranti Koherensi } & \multicolumn{4}{|c|}{ Jumlah data yang ditemukan } & \multirow[b]{2}{*}{ Jumlah } & \multirow[b]{2}{*}{$\%$} \\
\hline & & $\begin{array}{c}\text { Crème } \\
\text { Bienfaisante }\end{array}$ & $\begin{array}{c}\text { NIVEA } \\
Q 10\end{array}$ & $\begin{array}{l}\text { Idéalia Life } \\
\text { Serum }\end{array}$ & $\begin{array}{c}\text { ixxi } \\
\text { pearlixime }\end{array}$ & & \\
\hline 1 & $\begin{array}{l}\text { Hubungan makna } \\
\text { penambahan }\end{array}$ & 0 & 4 & 1 & 4 & 9 & 30 \\
\hline 2 & $\begin{array}{l}\text { Hubungan makna } \\
\text { kewaktuan }\end{array}$ & 4 & 1 & 2 & 0 & 7 & 23,34 \\
\hline 3 & Hub makna penjelas & 5 & 0 & 0 & 0 & 5 & 16,67 \\
\hline 4 & Hub makna kepemilikan & 1 & 0 & 1 & 0 & 2 & 6,67 \\
\hline 5 & Hub makna perbandingan & 0 & 1 & 0 & 0 & 1 & 3,34 \\
\hline 6 & Hub makna tujuan & 0 & 1 & 0 & 0 & 1 & 3,34 \\
\hline 7 & Hub makna tempat & 0 & 1 & 2 & 0 & 3 & 10 \\
\hline 8 & Hub makna persyaratan & 0 & 0 & 2 & 0 & 2 & 6,67 \\
\hline & Jumlah & 10 & 8 & 8 & 4 & 30 & 100 \\
\hline
\end{tabular}

36 atau 35,65\% dan konjungsi sebanyak 32 buah data $(31,69 \%)$, sedangkan jenis kohesi yang paling sedikit digunakan adalah kohesi leksikal sinonim dan hiponimi,yaitu masingmasing hanya terdapat 2 data $(1,98 \%)$. Penggunaan bahasa pada iklan harus singkat, jelas, padat, dan menarik, sehingga membutuhkan banyak elipsis untuk membangun kalimat yang efektif, praktis dan ekonomis. Elipsis juga berfungsi menimbulkan rasa penasaran atau ingin tahu dari pembaca terhadap hal-hal yang tidak diungkapkan dalam teks, sehingga dapat membuat bahasa iklan menjadi semakin menarik. Penggunaan bahasa dalam iklan harus padat dan jelas, sehingga wacana iklan tidak menggunakan teks yang panjang.

Dari Tabel 2 diketahui bahwa aspek koherensi yang digunakan dalam iklan Crème Bienfaisante, NIVEA Q10, Idéalia Life Serum, dan IXXI Pearlixime sangat bervariasi. Hal ini menunjukkan bahwa iklan tersebut merupakan wacana yang baik dan koheren. Wujud koherensi yang paling banyak digunakan untuk membentuk wacana yang koheren adalah hubungan makna kewaktuan $(23,34 \%)$, sedangkan yang paling sedikit digunakan adalah hubungan makna perbandingan dan tujuan, masing-masing $(3,34 \%)$. Banyaknya hubungan makna kewak- 
tuan pada wacana iklan tersebut menunjukkan bahwa perawatan kulit wajah harus dilakukan secara terus menerus dan dilakukan dengan teliti.

\section{Pembahasan}

Berdasarkan analisis mikrostruktural wacana iklan perawatan kulit wajah pada iklan Crème Bienfaisante, NIVEA Q10,dan Idéalia Life Serum, pada majalah Femme Actuelle edisi no. 1523 tanggal 2 sampai dengan 8 Desember 2013dapatditemukan aspek-aspek kohesi dan aspek-aspek koherensi, serta aspek-aspek makrostrukturalnya.

\section{Aspek kohesi}

Aspek kohesi meliputi kohesi gramatikal dan kohesi leksikal. Pada iklan tersebut terdapat kohesi gramatikal yang meliputi pengacuan, substitusi, elipsis, dan perangkai atau konjungsi. Pengacuan dan substitusi ditunjukkan dengan adanya satuan lingual:

(1) Textures fondantes, sensations inédites

Désormais votre peau se nourrit de plaisir. 'Tekstur lembut, sensasi baru

Sekarang kulit anda terpelihara dengan baik'

Satuan lingual votre peau pada tuturan (1) menjadi penanda adanya pengacuan yang berbentuk ajektiva posesif, ajektiva posesif ini merupakan pengacuan eksofora, karena acuannya berada di luar teks wacana, yaitu pembaca atau calon konsumen dari Crème Bienfaisante.

Aspek kohesi gramatikal juga ditemukan pada iklan Crème Bienfaisante, yaitu kohesi gramatikal yang berupa elipsis, perhatikan data berikut ini.

(2) Des textures fondantes et des sensations inédites. Désormais, votre peau se nourrit de plaisir

'Tekstur yang lembut dan sensasi baru. Sekarang kulit anda terpelihara dengan baik'

Pada data (2) terjadi elipsis, yaitu salah satu jenis kohesi gramatikal yang berupa penghilangan unsur (konstituen) tertentu. Unsur yang dilesapkan atau dihilangkan bisa berupa kata, frasa, klausa atau bahkan kalimat. Pada data (2), ada unsur yang dihilangkan. Jika unsur yang dilesapkan tersebut dimunculkan kembali, kemungkinan akan menjadi seperti pada kalimat

(2a) Crème Bienfaisante, les lers hydratants $24 \mathrm{~h}$ sur-mesure de Garnier vous offrent des textures fondantes et des sensations inédites. Désormais, votre peau se nourrit de plaisir

'Crème Bienfaisante, pelembab pertama tahan 24 jan produksi Garnier memberikan kepada anda tekstur kulit yang lembut dan sensasi baru. Sekarang kulit anda dapat terpelihara dengan baik'

Dengan demikian contoh (2) mengalami pelesapan pada unsur subjek Crème Bienfaisante, les lers hydratants 24 h sur-mesure de Garnier, predikat offrent, dan objek tak langsung vous.

Selanjutnya aspek kohesi leksikal pada iklan Novea Q10 ditemukan beberapa satuan lingual yang berkaitan dengan kohesi tersebut, yaitu yang berupa repetisi dan hiponim. Hal tersebut dapat dilihat pada data berikut ini. Satuan lingual yang terdapat pada data (3), (4), dan (5), merupakan contoh kohesi leksikal yang berupa repetisi.

(3) Q10 soin de jour Hydratant

Anti-rides + Hydrate la peau

Q10 soin de jour Texture légère

Anti-rides + resserre le pores

Q10 Crème d'énergi

$l^{\text {ères }}$ rides + reveille l'éclat

(4) Dès 40 ans

Peau sèche

Dès 40 ans

Peau mixte

Nouveau

Dès 30 ans

Peaux ternes et fatigues

(5) Nivea $Q 10^{\text {plus }}$ anti-rides

Soin de jour

Nivea $Q 10^{\text {plus }}$ anti-rides

Soin de jour

Texture légère

Nivea $Q 10^{\text {plus }}$ anti-rides 
Crème d'énergie

Reveille l'éclat de peau

Data (3) menunjukkan adanya repetisi atau pengulangan, yaitu satuan lingual Q10 soin de jour diulang sebanyak dua kali. Hal ini mengandung makna bahwa krim Nivea Q10 untuk jenis kulit apapun hanya digunakan untuk siang hari (de jour). Hal ini ditekankan lagi dengan adanya pengulangan satuan lingual soin de jour 'perawatan siang hari' seperti pada data (5). Kata rides yang berarti keriput atau kerut, juga diulang sebanyak tiga kali, itu artinya bahwa krim Nivea $Q 10$ ini berfungsi untuk mencegah munculnya keriput pada wajah atau pun menghilangkan kerut wajah, terutama pada kulit wajah perempuan. Contoh (4) menunjukkan adanya pengulangan satuan lingual Dès 40 ans dan Peau. Hal ini berfungsi untuk memberi penekanan bahwa krim Nivea Q10 ini hanya diperuntukkan bagi wanita berusia 40 tahun dan memiliki jenis kulit kering dan kombinasi, dan tidak bisa digunakan oleh wanita yang berusia di bawah 40 tahun.

\section{Aspek Koherensi}

Seperti telah dijelaskan di atas bahwa koherensi adalah keterkaitan antara bagian yang satu dengan bagian yang lainnya, sehingga kalimat memiliki kesatuan makna yang utuh. Pada iklan Crème Bienfaisante, koherensi atau kepaduan dapat ditemukan dengan adanya hubungan makna kewaktuan. Hubungan makna kewaktuan tersebut dapat dilihat pada data berikut ini.

(6) des textures fondantes et des sensations inédites Désormais, votre peau se nourrit de plaisir

\section{(7) Immédiatement: $+40 \%$ d'hydratation*}

Koherensi hubungan makna kewaktuan pada contoh (6) di atas ditandai dengan adanya adverbia Désormais 'selanjutnya' yang menunjukkan keterangan waktu, yaitu bahwa setelah menggunakan crème Bienfaisante kulit akan mendapatkan nutrisi atau makanan kulit yang lebih baik. Pada tuturan ini, pertalian makna kewaktuan terjadi pada tuturan des textures fondantes et des sensations inédites dan votre peau se nourrit de plaisir, yaitu tuturan pertama terjadi sebelum tuturan kedua.

Koherensi hubungan makna kewaktuan pada contoh (7) di atas ditandai dengan adanya adverbia Immédiatement 'dengan segera'yang menunjukkan sebagai keterangan waktu, yaitu bahwa setelah kulit wajah mendapatkan nutrisi dari crème Bienfaisante dengan segera akan menjadi lebih segar dan sensual, mencapai kelembaban lebih dari $40 \%$,

Pada iklan selanjutnya Nivea Q10, koherensi atau kepaduan dapat ditemukan dengan adanya hubungan makna antara satuan lingual yang satu dengan satuan lingual yang lain. Hubungan tersebut dapat dilihat pada data berikut ini.

(8) RÉVEILLEZ L'ÉCLAT DE VOTRE PEAU COMMEAPRĖS UNE BONNE NUIT DE SOMMEIL

Koherensi hubungan makna perbandingan pada contoh (8) di atas ditandai dengan adanya konjungsi comme 'seperti', yaitu membandingkan kecerahan kulit dengan segarnya setelah bangun tidur, dan sekaligus menunjukkan adanya hubugan makna kewaktuan yang ditandai dengan adanya preposisi après yang bermakna sesudah.

\section{Konteks Situasi dan Budaya}

Crème Bienfaisante berfungsi untuk melembabkan kulit wajah secara alami. Kita perlu melembabkan kulit, karena, terlepas dari jenis kulit, semua kulit tubuh manusia membutuhkan air. Tanpa air tubuh dan kulit kita tidak bisa berfungsi dengan baik. Permukaan kulit akan segera menunjukkan tanda-tanda kekuranganair (dehidrasi), yaitu kulit menjadi kering, kasar dan kusam. Kulit akan kehilangan kelembaban juga disebabkan faktor eksternal seperti polusi, sinar matahari, kelelahan, stres atau perubahan hormon. Kulit membutuhkan perhatian sehari-hari untuk mempertahankan tingkat kelembaban alami dan agar tetap berfungsi lebih baik. Hidrasi adalah cara terbaik untuk memerangi kerutan. Hidrasi adalah elemen kunci dalam mencegah tanda-tanda penuaan. Kulit terhidrasi lebih elastis dan fleksibel. Kita dapat melembabkan kulit dengan menggunakan krim, minyak dan lotion pagi dan sore pada 
seluruh wajah. Kebiasaan lain yang baik untuk tetap terhidrasi: Minum banyak air putih.

Tips kecantikan untuk kulit kering. Jika musim dingin datang kulit perlu terhidrasi. Karena cuaca musim dingin, angin dingin yang menggigit dan panas kering bisa menjadi mimpi buruk untuk kulit kering. Pemakaian krim lebih dipusatkan pada daerah yang paling kering. Jika daerah tertentu dari kulit wajah kering atau teriritasi, perlu memakai sejumlah besar pelembab pada daerah-daerah wajah sebelum tidur, keesokan harinya, kulit wajah akan lembut dan kenyal.

Cara yang harus dilakukan adaah membersihkan kulit wajah dengan formula lembut yang mencegah ketidaknyamanan dan membuat kulit wajah bersih, lembut dan kenyal. Apapun jenis kulit wajah, beberapa daerah lebih rentan daripada yang lain, seperti di sekitar mata, bibir dan leher. Sinar matahari dapat merusak kulit wajah, bahkan di musim dingin silau matahari selama bulan-bulan musim dingin dapat merusak kulit. Untuk melindungi kulit wajah dari kerusakan akibat sinar matahari, kita harus menggunakan SPF di wajah sepanjang tahun. Ini juga akan melindungi terhadap tanda-tanda penuaan. Mengoleskan krim atau lotion pada seluruh wajah adalah cara untuk melakukan hidrasi dari luar.

Iklan Crème Bienfaisante ini dimuatpada majalah Femme Actuelle no. 1523 du 2 au 8 décembre 2013. Iklan perawatan kulit wajah (kecantikan) Crème Bienfaisante ini merupakan iklan komersialyang bertujuan untuk memperoleh keuntungan komersial melalui transaksi jual belinya.Crème Bienfaisante adalah salah satu jenis krim untuk perawatan kulit wajah yang digunakan untuk melembabkan kulit secara alami, melembutkan dan nyaman di kulit wajah sepanjang hari,dan sebagainya .Krim ini dibuat oleh perusahaan yang bernama GARNIER atau Gemey Maybelline Garnier - SNC au capital de 49500 euros, 16 place Vendôme 75001 Paris - RCS Paris 339419 962. Iklan ini juga menampilkan lima gambar model dengan jenis kulit muka yang berbeda-beda.

Pada gambar model pertama (paling atas) menunjukkan model dengan jenis kulit muka kusam, kelihatan lelah (Peau fatiguée), sehingga krim yang harus dipakai untuk merawat kulit wajahnya adalah krim yang berjenis Gelée éclat 'jeli yang bersinar' yang terbuat dari Fleur d'Hibiscus 'bunga Hibitus'. Gambar model kedua (dari atas) menunjukkan model dengan jenis kulit normal (peau normal), krim yang harus digunakan untuk merawat kulit jenis normal ini adalah krim jenis Crème légère 'krim yg ringan', yang terbuat dari Fleur de Lotus 'bunga lotus'. Gambar model ketiga menunjukkan model dengan jenis kulit wajah kering (peau sèche). Jenis krim yang harus digunakan untuk merawat kulit wajahnya adalah jenis krim Baume nutritif 'Balsam yang penuh gizi', yang terbuat dari Huile de Camélia'minyak Camelia'

Gambar model keempat adalah model dengan jenis kulit wajah gelap (peau foncée). Jenis krim perawatan kulit yang harus digunakan adalah crème radieuse 'krim yang membuat berseri-seri' yang terbuat dari calendula (nama ilmiah untuk jenis tanaman yang berbunga kecil dan berwarna orange, digunakan untuk salep/ krim penyakit kulit)'. Gambar model yang terakhir adalah model dengan jenis kulit wajah kombinasi berminyak (peau mixte à grasse), sehingga krim perawatan kulit wajah yang harus digunakan adalah crème sorbet 'krim sari buah' yang terbuat dari thé vert 'teh hjau'

Setelah sepuluh tahun diluncurkan, Nivea Q10 masih tetap menjadi krim anti kerut atau keriput nomer satu di dunia. Krim perawatan anti kerut Q10 plus ini digunakan untuk siang hari, dan kini diperkaya dengan sistem filter $15 S P F$,yang secara aktif melindungi kulit wajah dari radiasi sinar.Keharuman baru untuk tekstur ringan meninggalkan sensasi menyenangkan pada kulit.

Ada tiga jenis produk Nivea Q10, pertama, Nivea $10^{\text {plus }}$ anti-ridessoin de jour yang merupakan krim anti kerut dan melembabkan kulit wajah. Krim ini digunakan untuk wanita yang berusia 40 tahun, yang pada usia ini biasanya kulit wajah menjadi mudah kering. Krim ini digunakan setiap hari pada siang hari. Kedua Nivea $Q 10^{\text {plus }}$ anti-rides,soin de jour, texture légère, krim ini merupakan krim anti keriput (kerut) dan dapat mengencangkan pori-pori. Krim ini sangat cocok untuk wanita berusia 40 tahun ke atas dan memiliki jenis kulit kombinasi (mixtes). Ketiga, Nivea Q10 ${ }^{\text {plus }}$, anti-rides, crème d'énergie-jour, Reveille l'éclat de la peau. 
Krim ini adalah produk terbaru dari Nivea, yang berfungsi untuk mencegak munculnya kerut (keriput) dan dapat membangkitkan pancaran kulit, serta mengurangi tanda-tanda kelelahan. Krim ini ditujukan bagi wanita beusia 30 tahun ke atas dan memiliki jenis kulit kusam dan lelah.

Nouveau IDÉALIA LIFE SERUM ada-

lah serum perawatan kulit wajah, untuk semua jenis kulit dan semua umur. Serum ini berfungsi untuk memberikan kesegaran dan warna yang homogen untuk seluruh permukaan kulit wajah. Serum ini sangat disarankan bagi kulit rusak akibat kena polusi udara, terlalu banyak bekerja, kecapaian, kurang tidur dan bahkan akibat kurang gizi. Dengan memakai serum ini, muka akan kelihatan segar, cerah dan bersinar. Kalimat pada iklan di bawah ini:

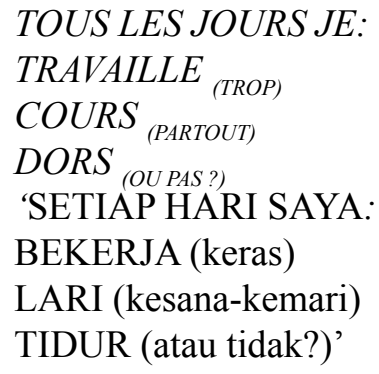

mengandung makna bahwa wanita yang setiap hari bekerja keras, $p$ ergi kemanamana atau lari kesana kemari, dan kurang tidur, maka akan berakibat kulit wajahnya terlihat kusam, capai, warna kulit tidak sama di seluruh permukaan, bahkan pori-pori kulit menjadi terbuka. Delapan hari kemudian penggunaan Nouveau IDÉALIA LIFE SERUM akan menemukan hasilnya, yaitu akan terjadi perubahan (transformstion) kualitas kulit yang dapat dilihat dengan nyata, bahkan dalam kondisi kehidupan yang sibuk. Kondisi seperti ini dijelaskan pada tuturan dalam iklan berikut ini'

Dès 8 jours, transformation

visible de la qualité de la peau, même en condition de vie intense 'sejak 8 hari, perubahan akan terlihat pada kualitas kulit, bahkan dalam kondisi kehidupan yang kuat'

\section{PENUTUP}

Secara mikrostruktural, penggunaan piranti kohesi dan koherensi dalam iklan perawa- $\tan$ kulit wajah sangat sedikit. Dari piranti kohesi gramatikal yang berupa pengacuan, substitusi, elipsis, dan konjungsi, maka elipsis adalah piranti yang paling banyak digunakan. Hal ini menunjukkan bahwa bahasa iklan harus bersifat singkat dan mudah dipahami oleh pembaca atau calon konsumen. Sementara itu, kohesi leksikal yang digunakan dapat berupa repetisi (pengulangan), sinonim, kolokasi, dan hiponmi.

Secara makrostruktural, iklan perawatan kulit wajah ini hanya diperuntukkan perawatan kulit wajah wanita dari segala usia, dengan jenis kulit yang berbeda-beda. Pada umumnya, perawatan kulit wajah bertujuan untuk membuat kulit wajah wanita tidak kelihatan tua, dengan cara mencegah timbulnya keriput atau bahkan menghilangkan keriput yang sudah terlanjur muncul. Di samping itu, kulit wajah wanita diharapkan harus selalu kelihatan segar, ceria, tidak kusam, tidak kelihatan capai, dan sebagainya. Perawatan kulit wajah ini juga harus dilakukan setiap hari, baik siang dengan krim siang dan maupun malam, dengan krim malam, serta serum yang bisa digunakan setiap saat

\section{UCAPAN TERIMA KASIH}

Artikel ini disarikan dari hasil penelitian mandiri yang dilaksanakan di Fakultas Bahasa dan Seni pada tahun 2014 dengan anggaran dana DIPA UNY tahun 2014 alokasi FBS. Ucapan terrima kasih kami sampaikan kepada DPP Penelitian FBS UNY, khususnya bidang bahasa, yang telah memfasilitasi penelitian ini hingga selesai. Ucapan terima kasih juga kami sampaikan kepada Rachma Wulan Maulida mahasiswa Jurusan Pendidikan Bahasa Prancis yang telah membantu pelaksanaan penelitian ini, dan juga kepada reviewer yang telah mengoreksi dan memberi masukan terhadap artikel ini.

\section{DAFTAR PUSTAKA}

Brown, Gillian and George Yule. 1983.Discourse Analysis. Cambridge: Cambridge University Press.

Darmiyati Zuchdi. 1993. Panduan Penelitian Analisis Konten. Yogyakarta: Lemlit IKIP Yogyakarta.

Hymes, Dell. 1972. Models of Interaction of Language and Social Life. Dalam John J. Gumperz and Dell Hymes. Directions 
in Sociolinguistics. USA: Holt, Rinehart and Winston, Inc.

Kesuma, Tri Mastoyo Jati, 2007, Pengantar (Metode) Penelitian Bahasa. Yogyakarta: Caraswatibooks.

Kridalaksana, Harimurti. 2008. Kamus Linguistik. Jakarta: PT Gramedia Pustaka Utama

Mahsun, MS, 2005. Metode Penelitian Bahasa : Tahapan, Strategi, Metode dan Tekniknya. Jakarta: Rajawali Pers.

Majalah Femme Actuelle edisi no. 1523 bulan Desember tahun 2013.

Mulyana. 2005. Kajian Wacana: Teori, Metode dan Aplikasi Prinsip-prinsip Analisis Wacana. Yogyakarta: Tiara Wacana.
Sumarlam, 2003. Teori dan Praktek: Analisis Wacana. Surakarta: Pustaka Cakra.

Suprapto, MS Tommy. 2009. Pengantar Teori dan Manajemen Komunikasi. Yogyakarta: Media Pressindo

Sudaryanto. 1993. Metode dan Aneka Teknik Analisis Bahasa: Pengantar Penelitian Wahana Kebudayaan secara Linguistis. Yogyakarta: Duta Wacana University Press.

Zaimar, Okke Kusuma Sumantri dan Ayu Basuki Harahap. 2009. Telaah Wacana. Jakarta: The Intercultural Institute 